Article

\title{
Hurdles to Forest Friendly Farming: Sustainability Lessons from Southeastern Mexico
}

\section{Eric Keys}

Department of Geography, University of Florida, 3141 Turlington Hall, Gainesville, FL 32611, USA;

E-Mail: ekeys@ufl.edu; Tel.: +1-352-376-0775; Fax: +1-352-392-8855

Received: 13 August 2010; in revised form: 20 September 2010 / Accepted: 21 September 2010 /

Published: 27 September 2010

\begin{abstract}
Worldwide the search is on for sustainable solutions to the competing needs for forest conservation and agricultural development. A strategy with contemporary salience arises in intensive, sedentarized agriculture that can protect forests and enhance livelihoods for forest dwellers. This paper investigates why intensive agriculture does not limit deforestation in southeastern Mexico's Calakmul Municipality. It argues that agriculture faces challenges from a range of biophysical and socioeconomic factors in tropical regions and that this encourages expanded land use for intensive farmers.
\end{abstract}

Keywords: sustainable agriculture; Mexico; tropical forests

\section{Introduction}

Conservation and development organizations continue to confront tropical deforestation and environmental change scientists continue to decry its pace and scale [1,2]. Research chronicles the causes of deforestation, ranging from large-scale logging to smallholder expansion [2,3]. Despite this research, slowing deforestation continues to vex policy makers, governmental and non-governmental conservation agents, and local people. These difficulties arise for many reasons but can be attributed to two sources, misunderstanding the driving forces of deforestation and the inability or unwillingness to change the driving forces $[2,4,5]$.

In Latin America tropical deforestation occurs in and near areas designated for colonization or frontier development. For example, Guatemala's Petén, South America's Amazonia, and Mexico's Maya Forest experience the highest rates of deforestation in the Western Hemisphere [6-9]. In the Maya Forest there is little evidence that clear cut logging drove initial deforestation although selective 
hardwood harvest came before the current deforestation period [10]. With no large-scale logging, smallholding farmers represent the drivers of land cover change [11,12]. Indeed, this is the case for Mexico's Calakmul Municipality which experienced rapid population growth between 1970 and 2000 as people migrated to gain access to agricultural land.

Conservation and development researchers and practitioners actively seek to find sustainable solutions to problems such as the agriculturally driven deforestation in southeastern Mexico. In this paper I investigate how commercial agriculture relates to deforestation on the edge of the Calakmul Biosphere Reserve, a protected tropical dry forest. I ask whether intensive commercial agriculture helps limit deforestation and helps improve farmers' livelihood as proposed in the literature on forest-friendly farming [13]. If chili cultivation can satisfy the needs of farmers while limiting deforestation, it holds promise as part of a sustainable development package for Latin America's forests. Rather than challenge the philosophical or ideological aspects of sustainability, this paper discusses how sustainable development is being played out on the ground in a specific locale, albeit one that represents many parts of the rural world in Latin America and most likely elsewhere.

Leading current efforts at sustainable development is the claim that intensive, commercial agriculture on limited amounts of land can both enhance household livelihoods and protect valued biomes [13-15]. In this paper I investigate the land use and land cover implications of intensive commercial agriculture, a livelihood strategy posited as potentially land sparing (that is with the potential to save "wild nature"). The results of research demonstrate that significant hurdles exist to enable intensive agriculture to spare land from cultivation and challenge the idea that agricultural land uses coincide with forest preservation. This paper focuses on the comparison of intensive commercial farmers with non-intensive subsistence farmers. The differences between the two groups of farmers demonstrates that the most intensive farmers, those most engaged in potentially land sparing activities, use the most forest and non-forest land. This result presents management challenges to near reserve areas and to the search for alternate livelihood strategies in tropical environments. The reasons for the increased land use among intensive farmers are manifold and include marketing arrangements, biological and pest dynamics, and the relatively recent inclusion of Calakmul into national and international markets. Thus, those targeted with limiting deforestation - intensive farmers - appear unable to do so. The imperfection of markets, vagaries of biophysical processes, and personal limitations of farmers ensures that intensive commercial agriculture does not limit deforestation.

For chili cultivation to satisfy both the needs of the farmers and their families and to limit deforestation it must satisfy overlapping criteria. First, cultivating chili must provide sufficient and stable income to allow farmers to intensify agriculture. Without this security, the farmers will be unlikely to cease other, more extensive agriculture or to invest capital in land improvements. For the price to be sufficient and stable, the national or regional chili marketing structure needs to allow farmers relatively equal access as it does farmers in other parts of the country. Likewise agricultural subsidies can help farmers bolster continued, intensive production. Second, the physical environment needs to encourage chili cultivation without major impediments. For the physical environment to encourage chili cultivation, abundant flat land, suitable for mechanization (intensification) should be available to farmers. Furthermore, the soils on the land should demonstrate the ability to sustain repeated cultivation. Finally, in terms of the physical environment, the occurrence of insect pests and plant plagues should be limited and allow farmers both traditional and non-traditional methods of combating them. 


\section{Study Site}

The Municipality of Calakmul (Calakmul) (Figure 1) lies in the southeastern Mexican state of Campeche. Calakmul borders the state of Quintana Roo to the east, Belize and Guatemala to the south, and the Municipalities of Calkini and Hopelchen to the west and north respectively (Figure 1). Calakmul also houses the Calakmul Biosphere Reserve (CBR), Mexico's largest such reserve dedicated to the protection of tropical forest and taking up more than 723,000 ha [10].

Figure 1. The Municipality of Calakmul, Mexico and Its Environs.

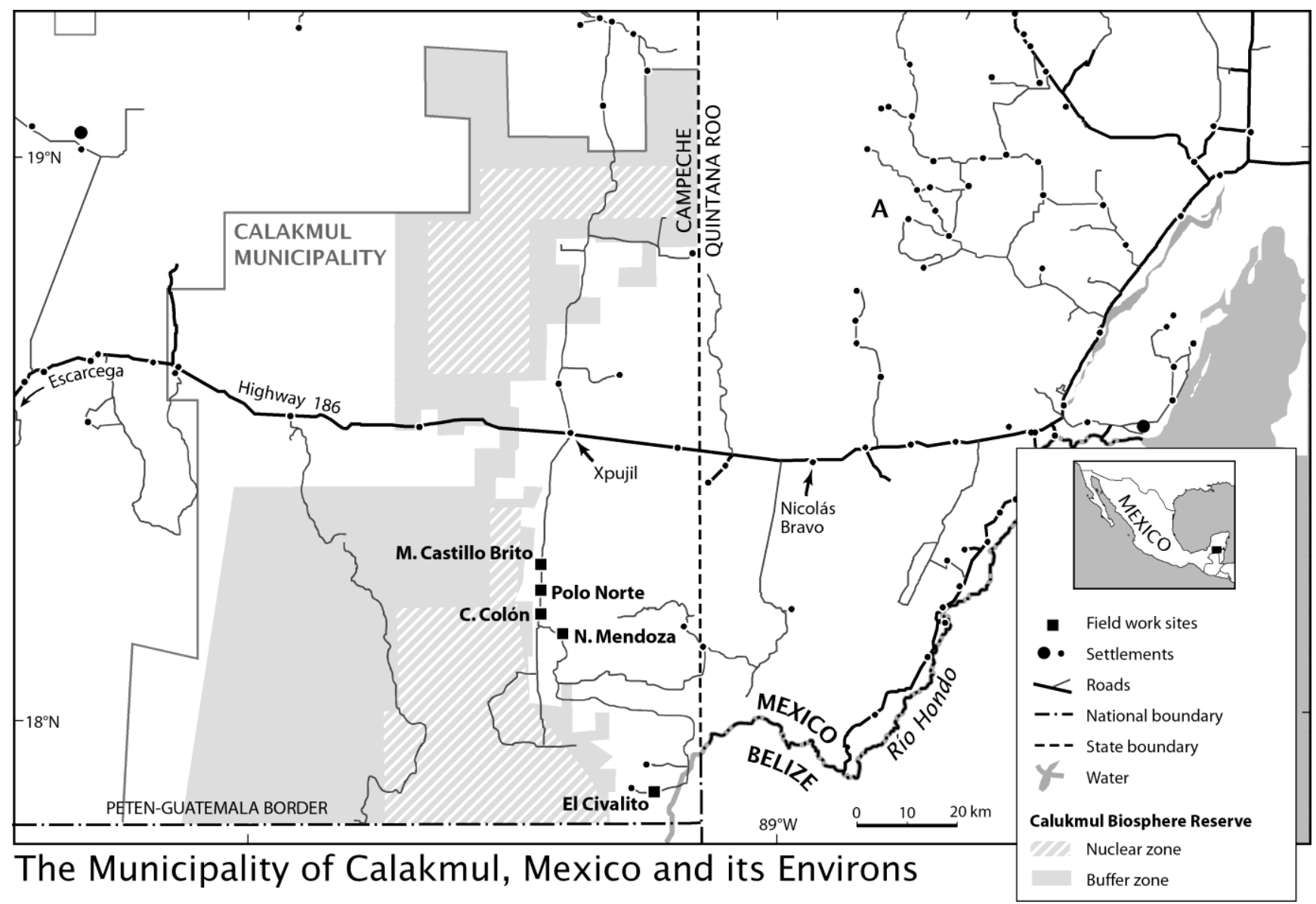

Numerous land cover types are in Calakmul, six of which are detailed for their importance relative to the goals of this paper. The most notable vegetation type consists of semi-evergreen/semi-deciduous forest of medium stature in the upland, seasonally dry areas of Calakmul. This is the dominant vegetation type in the region. Although most harvestable hardwoods have been removed selectively much of the Maya forest remains. Still other portions of the forest could be described as old secondary growth aged twenty or more years. Finally, wetland forests, locally called bajos, are of short stature although similar in terms of species composition to upland trees. Another vegetation type in the region are seasonally inundated savannahs, a third type of vegetation in the region is secondary vegetation, generally representing former agricultural land left fallow or dedicated to reforestation. Within these matrices of forest types there are endemic and rare plant species and locally threatened animals such as jaguar (Panthera onca), white lipped peccary (Tayassu pecari), Morlet's crocodile (Crocodylus moreletti) and others of interest to biological conservation. Agriculture is the last 
significant land-cover and varies from field agriculture for grains, to horticultural production for commodity markets, and to extensive pasture for cattle. The agricultural land cover portfolio of Calakmul varies but is generally made up of a mixture of pasture and field crops, mixed between grasses (maize) and vegetables (chilies, squash, and beans) in addition to limited citrus orchards. Recently, invasive species such as bracken fern (Pteridium aquilinum) and tajon (Viguera dentata) have begun to feature prominently in some ejidos after years of short fallowing [16].

Calakmul received significant in-migration of homesteaders enabled by the construction of Highway 186 beginning in the late 1960s and accelerating in the 1970s and 1980s, [12,17]. This was in part driven by the Federal Government's desires to populate a largely unoccupied frontier zone. Homesteaders, predominantly from Chiapas and Mexico's Gulf States, arrived with hopes of developing the land for agricultural uses. Initially distant from markets, most farmers engaged in slash and burn milpa (maize-beans-squash) agriculture primarily for local subsistence although this later gave way to efforts to commercialize agriculture with national market inclusion.

Population in the region grew from approximately 2,000 in 1970 to more than 30,000 in 2000, an increase of $1,500 \%$ over thirty years [18]. Most of the migrants settled in ejidos, lands managed communally following a Mexican Revolution agrarian reform. One agricultural idea, imported from sending communities, arose in the production of the jalapeno chili (Capsicum annuum L.) for sale on the Mexican national market was initiated by three farmers in 1975. After recruiting market intermediaries the production of chili grew rapidly, incorporating $85 \%$ of farmers in the southeast of Calakmul by 2000 [19].

In the late 1980s and early 1990s Calakmul became an experiment in conservation with development spurred by the 1989 proclamation and territorial definition of the Calakmul Biosphere Reserve (CBR) [20]. The CBR is central to land use policy and government/non-governmental organization's funding in the region. Initial development in Calakmul was geared toward agricultural frontier development, now nearly all development occurs, at least nominally, as conservation with development—part of Mexico's commitment to sustainable development [20].

With the introduction of the Calakmul Biosphere Reserve (CBR) in 1989, local politics and planning changed [20]. Although merely a paper park at first, by the mid-1990s the CBR drove the establishment of the Calakmul Municipality and its subsequent branding as Mexico's first "Eco-Municipio" (ecological municipality) [12]. Nearly all local political decisions are carried out with at least a cursory assessment of the environmental impacts of that decision. In addition, new monies arrived to Calakmul for various projects designed to enhance environmental sustainability in the region, primarily through the reduction of deforestation. Agroforestry alternatives, agroecological demonstration plots, and other innovations in general failed to recruit farmers. Somewhat more successful were efforts at reducing the use of agrochemicals through the introduction of legumes such as velvet bean (Mucuna pruriens L.). Finally, some actors in the region encouraged the sedentarization of agriculture through the introduction of mechanically worked fields. The primary methods designed to encourage mechanization arose in subsidies for tractor rental or purchase. It is hoped that the sedentarization of agriculture will allow farmers to produce more crops on less land and thus reduce their need to cut down forest.

These forest-friendly efforts are increasingly experimented with in the hopes of building win-win environment-development outcomes. Calakmul is an ideal place to experiment with these projects as funds are specifically earmarked for the ecomunicipio for conservation with development projects. 
The relatively new arrival of most residents in the region may prove ideal due to government and land user flexibility in terms of livelihood strategies. The remoteness of Calakmul, however, may provide significant challenges due to insufficiently varied avenues for marketing and alternate livelihood strategies. In southeastern Calakmul $91 \%$ of households are engaged in agriculture, most experimenting with mixed subsistence-commercial agriculture.

\section{Land Use and Land Cover Aspects of Different Cultivation Strategies}

In this paper I divide Calakmul's farmers according to their level of market involvement as an indicator of cultivation intensity [21,22]. Subsistence farmers plant and harvest for their household's consumption. Commercial farmers, representing the majority of farmers in the region exhibit a hybrid production strategy that relies on both subsistence and commodity crops (overwhelmingly chili) for survival.

Subsistence farmers depend primarily on the cultivation of maize (Zea mays L.), beans (Phaesolus vulgaris L.), and squash (Cucuribiticae) for household subsistence. Agricultural production is carried out using slash and burn (or "swidden") methods that begins with plot selection in January, tree cutting if a new plot is to be cultivated, burning in May, cultivation in early June to correspond with the beginning of the rainy season, intermittent weeding and care until late September or early October. In addition, subsistence farmers frequently engage in off farm employment as bricklayers, field hands, or in the service sector.

Two types of commercial farmers are found in Calakmul, those who farm commercially using slash and burn technology and those who farm with the use of tractors to till soil. All commercial farmers also farm milpa for home consumption and generally follow the same schedule for planting described above. Chili cultivation follows essentially the same seasonality as milpa cultivation although more steps are required.

Chili cultivation spread from one source community and a few hectares to every community and more than $50 \%$ of smallholders in the Calakmul Municipality as a whole [18]. In the southern part of Calakmul, where this study focused, 85\% of farmers cultivated chili in 1999 while 15\% farmed only for subsistence and earned cash otherwise [19,23]. During the 1999 season a high of 7,500 ha of chili were cultivated in Calakmul as a whole.

Chili cultivation has intensified and sedentarized with respect to agroindustrial inputs. Farmers' capital needs ballooned while the area cultivated annually among chili farmers expanded. Chili monoculture also fostered insect, plant, and microbial pests. To combat these pests, increasing amounts of pesticides, fungicides, bactericides, and herbicides are applied, compromising human health and ecological processes. Finally, chili cultivation exaggerates social class distinctions and cultural differentiation by demanding and encouraging a class of short-distance, day laborers while greatly increasing the wealth of a handful of smallholders.

Chili production takes two forms - mechanized and swidden (slash and burn) —although variations in both forms can be found in regard to capital inputs, hired labor, and basic attention given to the crop. Approximately $30 \%$ of southern Calakmul chili farmers use mechanized land, while the remaining $70 \%$ use swidden technologies. Farmers mechanize land by disking the cultivated area to loosen soils and turn organic matter underneath the surface. This practice encapsulates all the mechanized portion of cropping, 
and subsequent steps through to the harvest are undertaken by hand labor. Mechanized farmers tend to cultivate more land in chili than non-mechanized farmers (1.73 ha vs. $1.16 \mathrm{ha}$ ). They report, on average, higher yields and higher net and gross profits, and assume greater costs, and thus risk, due to higher amounts of labor and capital invested in the cultivation process, than swidden farmers.

Nearly all farmers interviewed expressed a desire to have their land mechanized and thus appear to be poised for intensification and sedentarization. Government and non-governmental programs encourage mechanization with the hopes that it will encourage "sedentarization" and intensification of agriculture. It bears mentioning that in no case did a farmer report abandoning mechanized land. Therefore, it seems that mechanization is in fact leading to sedentarization in some part as desired by NGOs and government agencies. However, mechanization in the region began in 1993 and time may not have been sufficient to force farmers onto new lands.

One of the initial goals of this paper lay in divining whether or not commercial agriculture promised to limit land use and land cover change. This section describes the differential land cover impacts of the land uses detailed above by separating farmer type between subsistence farmers and commercial farmers. Land use and land cover are discussed in terms of subsistence farmers, swidden chili farmers and mechanized chili farmers.

In terms of land use, chili farmers cultivate more land for milpa crops than other smallholders in the region, perhaps in an effort to expand their agricultural portfolio by increasing possible income from lower value but more securely priced crops (i.e., squash and beans). Figure 2 illustrates this observation. Note the increase in total area devoted to the range of crops moving from the non-chili to mechanized households. Chili farmers cultivate more land for milpa crops than non-chili farmers, and mechanized farmers more than non-mechanized farmers.

Figure 2. Land Uses by Farmer Type in Calakmul Municipality, Mexico, 1999-2000.

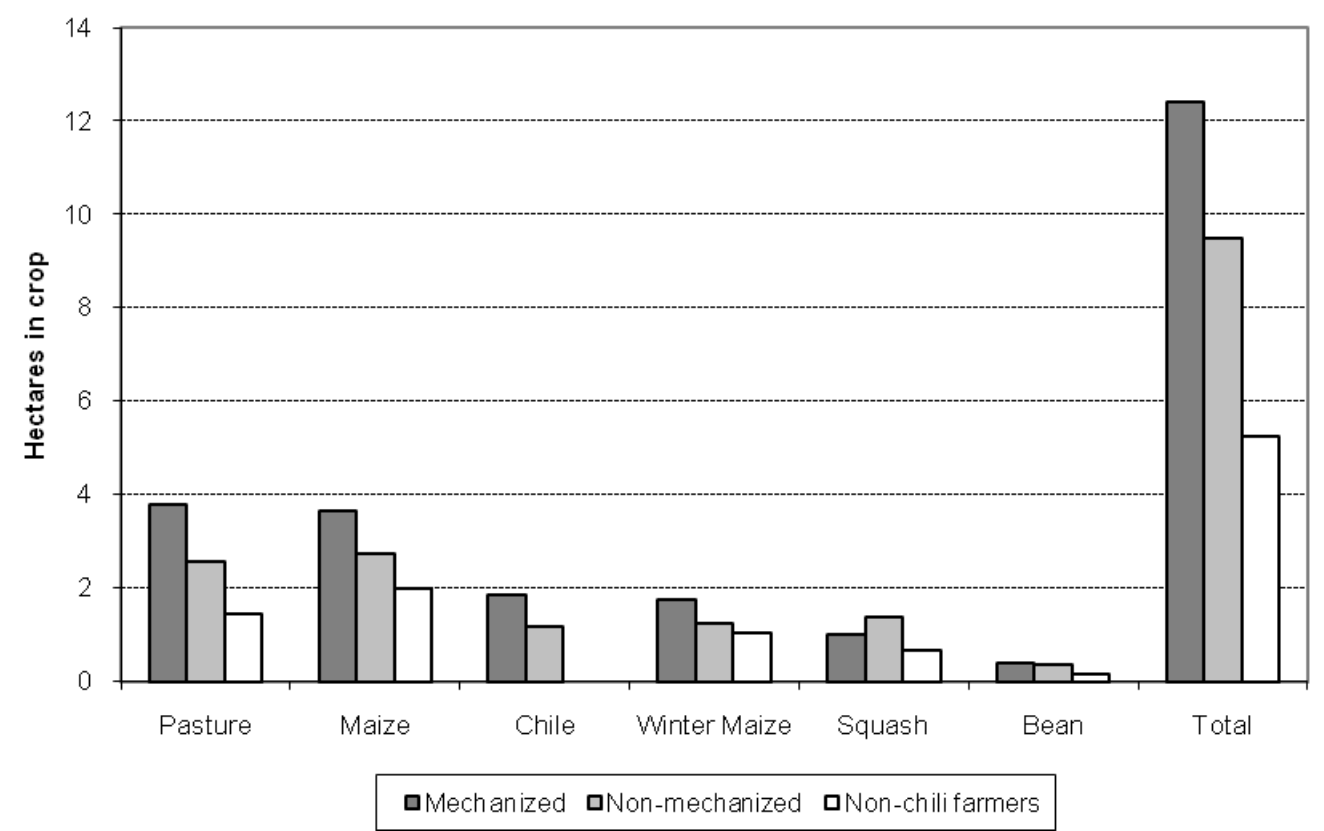

Because chili farmers cultivate more land, they might be expected to have less land in old growth forest. Figure 3 demonstrates the different land covers reported by farmers in the 1999 chili survey. 
Regrowth is any land that had been previously cultivated, but is in some state of succession. Old growth is any land that the farmer believed to have never been cultivated. Long-term agriculture describes lands that are either mechanized or pasture, and are unlikely to revert to forest in the near future. Short-term agriculture constitutes lands that are currently part of a swidden crop-fallow cycle and will be allowed to grow into forest in the near future. Mechanized chili farmers report holding the least amount of old growth land on their plots (Figure 3) and have the most land in uses not likely to convert back to forest in the near future. They also reported the most amount of land in regrowth and short-term agriculture.

Figure 3. Land Covers by Farmer Type in Calakmul Municipality, Mexico, 1999-2000.

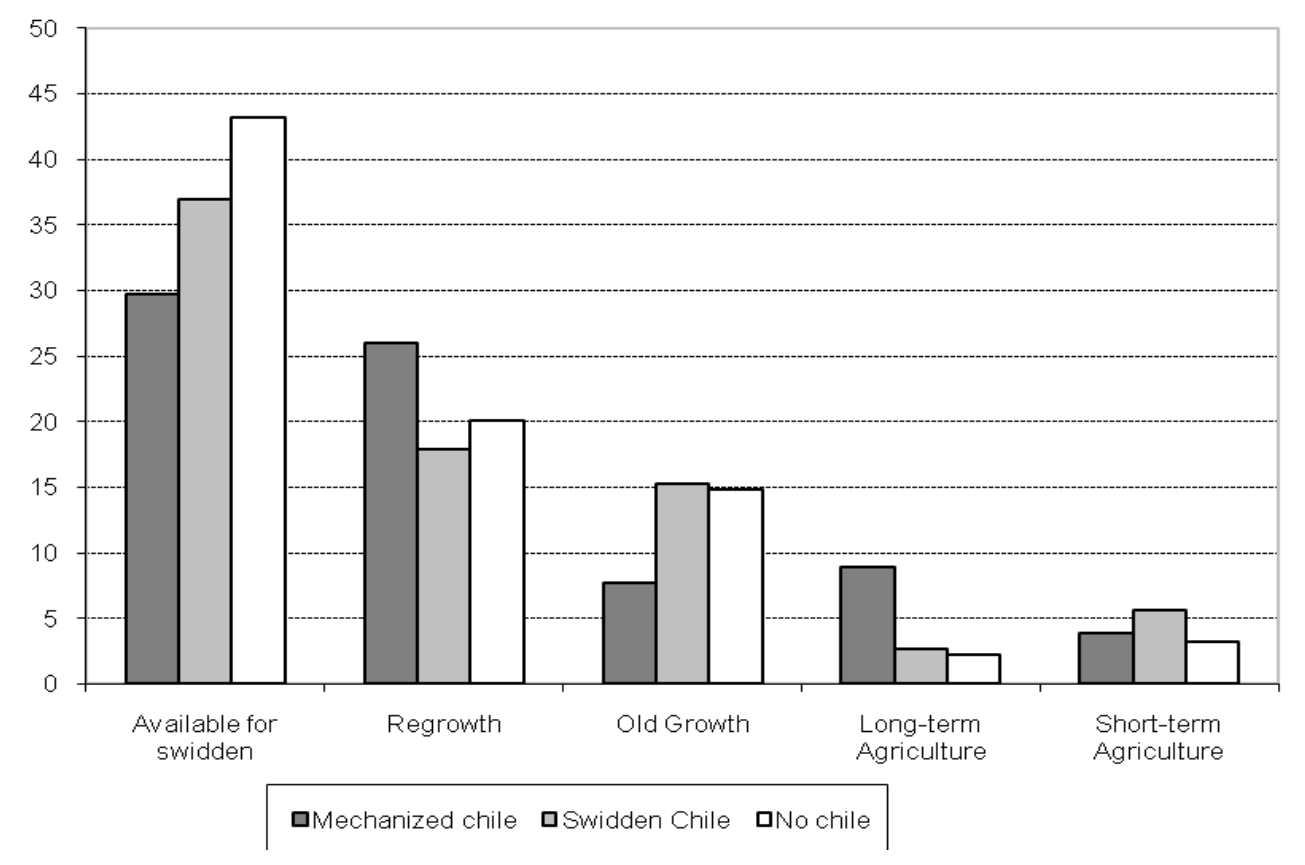

The reasons that chili farmers tend to use more land are varied but interrelated. Because they earn more money than most other farmers, they are more likely to hire labor from outside of their household for weeding, fumigation, clearing, and harvesting, expanding their agricultural portfolios. Expansion of the portfolios allows the farmer the opportunity to hedge against price fluctuations for their products. Increased wealth, it is assumed, gives farmers better connections to various government programs that promote access to subsidies of various kinds and to the latest "experiments" in cropping. Subsistence farmers who do not farm chili alter the least land and have the least in crops. These farmers, the least intensive, represent those that in fact disturb the least amount of land. Thus the hopes for land sparing from intensive cultivation are not satisfied.

\section{Discussion}

During the past 40 years, farmers in Calakmul shifted from the production of milpa crops for their own consumption and occasional sale to relying on chili for income while using milpa crops to feed their families. Chili today is the single most important income generator for the majority of the region's farmers, and the cash it generates supports many of the region's retail stores and supply outlets. Furthermore, chili cultivation commands a central place in governmental and non-governmental policy efforts. In terms of the area devoted to it, chili holds second place only to milpa crops. But, in the way 
that it ties farmers to a wider national market and government structures, chili far outshines any other agriculture in Calakmul.

To understand the reasons that intensive, commercial agriculture does not spare forest land from cutting it is important to recognize the difficulties in cultivating that crop that arise from biophysical, household, commodity market and the Mexican political economy (Table 1). Particular discussion of the various stages of cultivation and sale is not discussed and can be found elsewhere [24]. In Calakmul, chili cultivation represents the most intensive form of cultivation requiring 152 days of labor on average compared to less than 100 for maize cultivation. In total, chili farmers expend more than 250 days of labor each year, the most intensive investment of labor in Calakmul agriculture. Because each stage of cultivation requires farmers to consider multiple factors chili farming becomes a high-risk and complicated endeavor in which neither cropping success nor sale can be assured [19,24]. This lack of confidence in the crop leads farmers to diversify their farming portfolios (Figures 2 and 3) and increase the overall amount of land used by them. Thus, rather than sparing land, intensive (measured in terms of labor allocated to production) cultivation is more consumptive of land than the alternate, less intensive form of agriculture.

Table 1. Factors that limit the intensification potential of chili peppers, Calakmul Municipality, Mexico, 1999-2000.

\begin{tabular}{|c|c|c|c|c|c|}
\hline & Biophysical & Household & Community and Region & National Market & Policy \\
\hline $\begin{array}{l}\text { Plot } \\
\text { selection }\end{array}$ & $\begin{array}{l}\text { Quality of } \\
\text { vegetation, } \\
\text { distance, soil } \\
\text { factors }\end{array}$ & $\begin{array}{l}\text { Attitude toward } \\
\text { forest, household labor } \\
\text { availability, available } \\
\text { capital }\end{array}$ & $\begin{array}{l}\text { Available labor } \\
\text { in community }\end{array}$ & $\begin{array}{l}\text { Predicted price } \\
\text { of chili }\end{array}$ & $\begin{array}{l}\text { Government } \\
\text { and NGO } \\
\text { policies }\end{array}$ \\
\hline Felling & $\begin{array}{l}\text { Thickness of } \\
\text { trees, density } \\
\text { of undergrowth, } \\
\text { soil moisture }\end{array}$ & $\begin{array}{l}\text { Labor availability, } \\
\text { physical fitness, tools } \\
\text { available, capital } \\
\text { availability }\end{array}$ & $\begin{array}{l}\text { Available labor in } \\
\text { community }\end{array}$ & - & $\begin{array}{l}\text { Government } \\
\text { and NGO } \\
\text { policies }\end{array}$ \\
\hline Burning & $\begin{array}{l}\text { Timing of } \\
\text { rainfall, dryness } \\
\text { of vegetation }\end{array}$ & Labor availability & - & - & $\begin{array}{l}\text { Government } \\
\text { and NGO } \\
\text { alternatives } \\
\text { and } \\
\text { prohibitions }\end{array}$ \\
\hline Sowing & $\begin{array}{l}\text { Soil moisture, } \\
\text { quality of seeds, } \\
\text { weeds present }\end{array}$ & $\begin{array}{l}\text { Labor availability, } \\
\text { past experience with } \\
\text { planting, seeds stored } \\
\text { from previous year }\end{array}$ & $\begin{array}{l}\text { Available labor in } \\
\text { community, quality of } \\
\text { available labor, seed held } \\
\text { by other farmers }\end{array}$ & $\begin{array}{l}\text { Predicted price of } \\
\text { chili, availability and } \\
\text { cost of commercial } \\
\text { seed and preparing } \\
\text { seed chemical } \\
\text { preparations }\end{array}$ & $\begin{array}{l}\text { Government } \\
\text { supplied } \\
\text { improved } \\
\text { seeds, NGO } \\
\text { technical } \\
\text { planting advice }\end{array}$ \\
\hline
\end{tabular}


Table 1. Cont.

\begin{tabular}{|c|c|c|c|c|c|}
\hline & Biophysical & Household & Community and Region & National Market & Policy \\
\hline $\begin{array}{l}\text { Weeding, } \\
\text { fumigating }\end{array}$ & $\begin{array}{l}\text { Frequency and } \\
\text { severity of pest } \\
\text { outbreaks, } \\
\text { timing and } \\
\text { abundance of } \\
\text { rainfall, gravity } \\
\text { of wind, } \\
\text { temperature }\end{array}$ & $\begin{array}{l}\text { Labor availability, } \\
\text { experience in care, } \\
\text { capital availability for } \\
\text { chemical applications, } \\
\text { attitude toward } \\
\text { chemicals }\end{array}$ & $\begin{array}{l}\text { Available labor, advice } \\
\text { from other farmers and } \\
\text { coyotes }\end{array}$ & $\begin{array}{l}\text { Cost of chemicals, } \\
\text { advice from sellers }\end{array}$ & $\begin{array}{l}\text { NGO and } \\
\text { Gov't. } \\
\text { alternatives to } \\
\text { chemical } \\
\text { applications }\end{array}$ \\
\hline Harvest & $\begin{array}{l}\text { Quality and } \\
\text { abundance of } \\
\text { growth, weather } \\
\text { and pest patterns }\end{array}$ & $\begin{array}{l}\text { Labor availability, } \\
\text { capital availability for } \\
\text { hiring labor }\end{array}$ & $\begin{array}{l}\text { Labor availability and } \\
\text { cost, quality of labor. Sale } \\
\text { arrangements with coyotes }\end{array}$ & Price of crop & - \\
\hline Sale & $\begin{array}{l}\text { Quality of fruit, } \\
\text { marks from pests }\end{array}$ & $\begin{array}{l}\text { Relationship with } \\
\text { coyote }\end{array}$ & $\begin{array}{l}\text { Information on prices from } \\
\text { neighbors. Sale } \\
\text { arrangements with } \\
\text { coyotes, social connection } \\
\text { to coyote }\end{array}$ & $\begin{array}{l}\text { price of crop, coyote } \\
\text { willingness to pass } \\
\text { losses on }\end{array}$ & $\begin{array}{l}\text { Alternative } \\
\text { marketing } \\
\text { options } \\
\text { (cooperative) }\end{array}$ \\
\hline
\end{tabular}

Although jalapeño is the dominant cash crop in the Municipio de Calakmul and the region in general, the production and sale of the peppers varies significantly from year to year. Linked to the national market through coyotes, chili farmers complain of inconsistent prices for their crop. For example, the average price per kilo in 1998 was $\mathrm{N} \$ 1.43$, while in 1999 the average price per kilo was $\mathrm{N} \$ 2.09$. These price fluctuations are linked to the state of chili production elsewhere in Mexico. States in northern and central Mexico historically dominated chili production in the country and have long-standing ties to food-processing companies and intermediaries, and greater access to agricultural technologies, such as mechanization, refrigeration, and chemical applications. Due to this, and perhaps to environmental factors, the north tends to produce a superior chili compared to the southern Yucatán peninsular region. All else being equal, these areas constitute the primary and secondary suppliers. Calakmul and the larger region is best seen as a tertiary supply region, whose crop increases in value when demand is not met by the other areas, due to bad weather (e.g., killing frost), pest outbreaks, and so forth. The production in the primary regions of the country was high in 1998, and Calakmul chili prices were low. In 1999, frosts and pest attacks in the north of Mexico lowered the total national supply, and the prices were relatively high in Calakmul.

The future of chili in the region and its environmental implications are not so obvious, despite the crop's fast spread. The large flux in the farm gate prices suggests that a profitable but more stable substitute might readily shift commercial practices. Beyond this, the novelty of labor and capital intensive input cultivation of this kind opens many questions about its ecological and economic sustainability. Chili cultivation engenders certain biophysical constraints. Pests and soil degradation appear to be growing based on the increased chemical inputs to the land. And, despite intensification, the more commercial and capital oriented the household becomes, the more of its lands are taken into cultivation and the less that remain in older growth forest. Chili cultivation, therefore, has triggered a 
new set of economic and ecological relationships that must be taken into account in understanding and projecting deforestation and land change in Calakmul.

\section{Conclusions}

At the outset, I posed a question for itself, namely: can the intensive commercial cultivation of the chili jalapeño promote higher incomes on less land, thereby improving farmer's welfare while limiting deforestation? This question addressed both theoretical and practical considerations operating in the Calakmul Municipality. Policy and loan agencies from outside the region hope that farmers will develop and sustain land-use practices that do not compromise the region's wet-dry forest and, most importantly, the Calakmul Biosphere Reserve.

The expanded land use portfolios of Calakmul farmers demonstrate some of the linkages that the chili farmers encounter when deciding where to plant, when to plant, how to cultivate, and how much produce to sell. These decisions are broken out along five sources of decision-making influence. Biophysical factors, such as soil quality, precipitation, and pest abundance influence the ways that farmers act. The farmer also is faced with assessing the personal or household constraints and strengths of the household. These personal factors can include labor availability, farmer knowledge, and capital availability among others. The social aspects of the farmer's community also influences the ways that he acts. The availability of local labor, the quality of that labor, and the farmer's ability to interact and negotiate work with others ends up being important to the success of cultivation. Extra-local (national or regional) social relationships also play an important role especially in terms of the relationships that the farmer has with the coyote. The wider national market also interacts with farmers in that it decides the price that a farmer can hope to get from chili cultivation. Finally, NGOs and government organizations set policies and offer alternatives to farmers that influence the methods of cultivation and the attitudes that the farmer has toward forest use and tree felling.

While the complexity of the relationships in chili cultivation and marketing are demonstrated in the above tables, it is not clear whether or not this activity can improve livelihoods for the farmers of the region. Without improved livelihoods, farmers will be loath to abandon subsistence cultivation. Thus, increased land use and the corresponding increases in land-cover change promise to continue to alter the forests and secondary vegetation of the region. The reasons that farmers are unwilling to abandon cultivation seem to derive from the fact that at nearly every link in the chili-to-market chain they are confronted with multiple factors that make their cultivation insecure. These relationships are neither surprising, except in their particular configurations, nor are they unusual. Farmers everywhere face production constraints from a variety of biophysical, social, and cultural forces. But what differentiates the chili farmers of Calakmul from some other farmers is that even given these constraints, the value of their production is so unpredictable and variable that they cannot yet begin to think of chili as a guaranteed market crop even if they were given ideal agro-climatic conditions.

What is clear, however, is that chili cultivation, as it is currently practiced and in all likelihood will be practiced in the near future, does not promise to limit expansion of mature growth forest clearance. Those farmers most involved in chili are those that have the most land in long-term and short-term agriculture and have the least amount of land in old growth forest, controlling for ejido size and length of occupancy. These farmers exploit the forest resources available to them because, quite frankly, they can. 
The insecure price structure of chili encourages those farmers with the most money to hedge their bets more than other farmers who are less economically able to do so. The most intensive area of chili cultivation, on the southern road at the edge of the biosphere reserve, also threatens to expand eventually into the reserve itself. In this area, $462 \mathrm{~km}^{2}$ of forest fell to farming during the mid 1980s to mid 1990s, consuming more forest land than anywhere else in the larger region [25].

Whether or not chili promises to enhance the lives of smallholders in Calakmul is a secondary and important consideration. Without livelihood benefits, we can expect chili to continue along its environmentally destructive path. The lessons of livelihood improvement in Calakmul are mixed. Some farmers are able to profit from chili cultivation to the extent that they have entered into business with coyotes. These farmers build impressive houses, own trucks and sometimes tractors, and are able to plan future cultivation and investments as entrepreneurs. Others however, earn much of their cash as family based itinerant harvesters of chili. The ability of these farmers to pull themselves out of poverty is unclear although not hopeful. Farmers are unable to invest cash into their chili crops to mechanize land, purchase agrochemicals, and hire labor when it is needed. Absent alternatives, most of the farmers of southern Calakmul have little choice but to continue chili cultivation. The alternatives presented to them, such as allspice, organic farming, and fruticulture, seem as risky to farmers as chili cultivation. They are more apt to work within a system that they are somewhat familiar with than to risk total ruin by engaging in new activities.

In principle, the ideas promoted by Green and others [13] and Balmford and others [15] promise to attain the elusive win-win of human-environment relationships, namely enhancing conservation while enriching and feeding people in the developed and developing worlds. Where these ideas fall short however, lies in the difficulty of applying them to real world settings. Many agricultural land uses occur within imperfect market systems and challenging physical environments which makes the land sparing approach falter under scrutiny. In addition, already farmed land may not be ideal for intensive agriculture; there are compelling reasons to fallow land: pests, nutrient decline, and the like. Finally, cultural and social factors combine to make long-term, intensive cultivation a difficult proposition. In their simplicity, suggestions to alter deforestation patterns through the promotion of intensive cultivation ignore the multifaceted challenges of tropical agriculture.

\section{References}

1. Fearnside, P.M. Conservation policy in Brazilian Amazonia: Understanding the dilemmas. World Develop. 2003, 31, 757-779.

2. Rudel, T.K. Tropical Forests: Regional Pathways of Destruction and Regeneration in the Late Twentieth Century; Columbia University: New York, NY, USA, 2005.

3. Keys, E.; McConnell, W. Global Change and the Intensification of Agriculture in the Tropics. Global Environ. Change 2005, 15, 320-337.

4. Lambin, E.F.; Turner, B.L., II; Geist, H.J.; Agbola, S.B.; Angelsen, A.; Bruce, J.W.; Coomes, O.T.; Dirzo, R.; Fischer, G.; Folke, C.; George, P.S.; Homewood, K.; Imbernon, J.; Leemans, R.; Li, X.; Moran, E.F.; Mortimore, M.; Ramachandran, P.S.; Richards, J.F.; Skanes, H.; Steffen, W.; Stone, G.D.; Svedlin, U.; Veldkamp, T.A.; Vogel, C.; Xu, J. The Causes of Land-use and Land-cover Change: Moving Beyond the Myths. Global Environ. Change 2001, 11, 261-269. 
5. Shriar A.J. The Dynamics of Agricultural Intensification and Resource Conservation in the Buffer Zone of the Maya Biosphere Reserve, Petén, Guatemala. Hum. Ecol. 2001, 29, 27-48.

6. Jones, J. Colonization and Environment: Land Settlement Projects in Central America; United Nations University: Tokyo, Japan, 1990.

7. Schmink, M.; Wood, C.H. Contested Frontiers in Amazonia; Columbia University: New York, NY, USA, 1992.

8. Moran, E.F. Deforestation and Land Use in the Brazilian Amazon. Hum. Ecol. 1993, 21, 1-21.

9. Walker, R.; Homma; A.K.O. Land use and land cover dynamics in the Brazilian Amazon. Ecol. Econ. 1996, 18, 67-80.

10. Klepeis, P.; Turner, B.L., II. Integrated land history and global change Science: The example of the southern Yucatan Peninsular region project. Land Use Policy 2001, 18, 27-39.

11. Acopa, D.; Boege; E. The Maya Forest in Campeche, Mexico: Experiences in Forest Management at Calakmul. In Timber, Tourists, and Temples: Conservation and Development in the Maya Forest of Belize, Guatemala, and Mexico; Primack, R.D., Bray, D.B., Galletti, H.A., Ponciano, I., Eds.; Island: Washington, DC, USA, 1998; pp. 81-97.

12. Turner, B.L., II; Geoghegan, J.; Foster, D.R. Integrated Land-Change Science and Tropical Deforestation in the Southern Yucatán: Final Frontiers; Clarendon Press of Oxford University: Oxford, UK, 2004.

13. Green, R.; Cornell, S.J.; Scharlemann, J.W.P.; Balmford, A. Farming and the fate of wild nature. Science 2005, 307, 550-557.

14. Matson, P.A.; Vitousek, P.M. Agricultural intensification: Will land spared from farming be land spared for nature? Conserv. Biol. 2006, 20, 709-710.

15. Balmford, A.; Green, R.E.; Scharlemann, J.P.W. Sparing land for nature: Exploring the potential impact of changes in agricultural yield on the area needed for crop production. Glob. Change Biol. 2005, 11, 1594-1605.

16. Schneider, L.; Geoghegan, J. Land Abandonment in an Agricultural Frontier after a Plant Invasion: The Case of Bracken Fern in Southern Yucatan, Mexico. Aust. J. Agric. Resour. Econ. 2006, 35, 167-177.

17. Turner, B.L., II; Cortina Villar, S.; Foster, D.; Geoghegan, J.; Keys, E.; Klepeis, P.; Lawrence, D.; Macario Mendoza, P.; Manson, S.; Ogneva-Himmelberger, Y.; Perez Salicrup, D.; Roy Chowdhury, R.; Savitsky, B.; Schneider, L.; Schmook, B.; Vance, C. Deforestation and agricultural change in the southern Yucatan Peninsular region: Integrative land change for global change studies. For. Ecol. Manage. 2001, 154, 353-370.

18. Klepeis, P. Development policies and tropical deforestation in the southern Yucatan Peninsula: Centralized and decentralized approaches. Land Degrad. Develop. 2003, 14, 541-561.

19. Keys, E. Market intermediaries link farms to markets: Southeastern Mexican examples. Geogr. Rev. 2005, 95, 24-46.

20. Haenn, N. Fields of Power, Forests of Discontent: Culture, Conservation, and the State in Mexico; The University of Arizona: Tucson, AZ, USA, 2005.

21. Comparative Farming Systems; Turner, B.L., II, Brush, S.B., Eds.; The Guilford: New York, NY, USA, 1987. 
22. Klepeis, P.; Vance, C. Neoliberal policy and deforestation in southeastern Mexico: An assessment of the PROCAMPO program. Econ. Geogr. 2003, 79, 221-240.

23. Keys, E.; Roy Chowdhury, R. Cash crops, smallholder decision making and institutional interactions in a closing frontier, Calakmul, Campeche, Mexico. J. Lat. Amer. Geogr. 2006, 5, 75-90.

24. Keys, E. Chili cultivation in the southern Yucatan region: Plant-pest disease as land degradation. Land Degrad. Develop. 2004, 15, 397-409.

25. Roy Chowdhury, R. Landscape changes in the Calakmul Biosphere Reserve, Mexico: Modeling the driving forces of smallholder deforestation in land parcels. Appl. Geogr. 2006, 26, 1129-1152.

(C) 2010 by the authors; licensee MDPI, Basel, Switzerland. This article is an open access article distributed under the terms and conditions of the Creative Commons Attribution license (http://creativecommons.org/licenses/by/3.0/). 